JURNAL KETAHANAN NASIONAL

ISSN: 0853-9340 (Print), ISSN: 2527-9688 (Online)

Online sejak 28 Desember 2015 di: http:/jurnal.ugm.ac.id/JKN

VOLUME 23

No. 1, 27 April 2017

Halaman 68-85

\title{
Partisipasi Pemuda Purna Paskibraka Indonesia Dalam Kegiatan Bela Negara Dan Pengaruhnya Terhadap Ketahanan Wilayah (Studi Tentang Purna Paskibraka Indonesia Kabupaten Klaten Provinsi Jawa Tengah)
}

\author{
Erdi Wikan Febrihananto \\ Ketua Dewan Penasehat Pratiyodha Paramita \\ Organisasi Pasukan Pengibar Bendera SMA Negeri 1 Klaten \\ Email: erdi.wikan@gmail.com \\ Irwan Abdullah \\ Fakultas Ilmu Budaya Universitas Gadjah Mada \\ Email: i.abdullah@cpps.or.id \\ Ahmad Zubaidi \\ Fakultas Filsafat Universitas Gadjah Mada \\ Email:zub@ugm.ac.id
}

\begin{abstract}
This research discussed about the participation of youth in defending the country and its influence to the regional resilience at the Klaten Regency.

This research used qualitative research method, object the research was the youth's participation to defending the country and its implications to the regional resilience. The method of collecting data were interview, observation, literature study, documentation study, and online page search. Data analysis techniques in this study using data reduction, data presentation, and conclusion.

The results showed that Former Flag Raisers of Indonesia, Klaten Regency had of participate in activity to defending the country in the Klaten Regency. The participation performed by four models activities, namely model of ideological activity, model of social interaction activity, competition between Paskibra, and model of acting activity. It's participation gave the comprehension about defending the country, awareness about defending the country, and commitment about defending the country. The participation of Youth to defending the country had influences for the regional resilience at the Klaten Regency with criteria that included aspects of ideology, politic, social and cultural, and defense and security.
\end{abstract}

Keywords: Participation of Youth, Defending the Country, Regional Resilience

\begin{abstract}
ABSTRAK
Penelitian ini membahas tentang partisipasi pemuda dalam kegiatan bela negara dan pengaruhnya terhadap ketahanan wilayah Kabupaten Klaten. Dengan menggunakan metode penelitian kualitatif, penelitian ini memfokuskan kajiannya pada partisipasi pemuda dalam kegiatan bela negara dan pengaruhnya terhadap ketahanan wilayah di daerah Klaten, Jawa Tengah. Metode pengumpulan data pada penelitian ini menggunakan wawancara, observasi, studi
\end{abstract}


pustaka, studi dokumentasi, dan penelusuran laman online. Teknik analisis data pada penelitian ini menggunakan reduksi data, penyajian data, dan penarikan kesimpulan.

Hasil penelitian menunjukkan bahwa Purna Paskibraka Indonesia telah berpartisipasi secara aktif dalam kegiatan bela negara di Kabupaten Klaten. Partisipasi tersebut dilakukan melalui 4 (empat) model kegiatan yaitu kegiatan yang bersifat ideologis, kegiatan yang bersifat interaksi sosial, kegiatan kejuaraan antar Paskibra, dan kegiatan bersifat aksi. Partisipasi tersebut memberikan pemahaman terhadap nilai-nilai berbangsa dan bernegara yang kemudian memberikan kesadaran terhadap kewajiban bela negara, dan menyatakan komitmennya terhadap bela negara. Partisipasi pemuda dalam kegiatan bela negara ini berpengaruh terhadap ketahanan wilayah Kabupaten Klaten terutama dalam konteks penguatan ideologi, katahanan politik, sosial dan budaya budaya serta memperkokoh aspek pertahanan dan keamanan.

Kata Kunci: Partisipasi Pemuda, Bela Negara, Ketahanan Wilayah

\section{PENGANTAR}

Perubahan yang terjadi di Indonesia selama setengah abad ini telah membawa masyarakat ke arah yang penuh dengan fragmentasi dan kohesi sekaligus (Abdullah, 2006:77). Globalisasi telah membawa manusia dalam pergaulan antar bangsa yang luas, dan termasuk di dalamnya semakin pentinga peran teknologi informasi serta komunikasi yang tidak mengenal batas. Globalisasi membuat masyarakat di suatu negara lebih terbuka terhadap masuknya teknologi baru, sehingga memiliki wawasan yang lebih luas, dan membuat batas antara masyarakat di suatu negara dengan negara lain lebih dekat. Di sisi lain, globalisasi juga membawa pengaruh negatif bagi pranata kehidupan sosial dan budaya masyarakat. Misalnya masuknya budaya yang bertentangan dengan budaya di Indonesia yang pada gilirannya mampu mempengaruhi masyarakat Indonesia untuk meninggalkan budaya bangsanya sendiri.

Perkembangan teknologi di era globalisasi membawa Indonesia pada tantangan yang baru Dahulu, peperangan dilakukan secara konvensional dengan menggunakan senjata dan pasukan militer. Era selanjutnya bergeser pada kepemilikan senjata nuklir sebagai alat untuk menangkal ancaman dari negara lain. Sekarang ini peperangan telah bergeser pada jenis peperangan modern melalui kultur, diplomasi, teknologi, komunikasi dan ideologi yang dapat dijadikan sebagai senjata untuk menyerang dan menjajah negara lain. Penjajahan pun bergeser bukan lagi pada kepemilikan wilayah secara de jure namun pada kepemilikan sumber daya strategis dan sumber kekuatan ekonomi.

Pada konteks Indonesia, ancaman, tantangan, hambatan, dan gangguan pun ikut mengalami pergeseran. Ancaman, tantangan, hambatan dan gangguan yang dihadapi oleh bangsa Indonesia bukan lagi dalam bentuk agresi militer akan tetapi berupa penjajahan ideologi, politik, ekonomi dan sosial budaya. Di sinilah globalisasi memegang peranan sebagai pembawa arus ancaman tersebut dari luar menuju ke Indonesia.

Pada masa globalisasi yang sedang terjadi sekarang ini tantangan zaman semakin berat, tuntutan akan kemampuan beradaptasi dengan perubahan semakin menguat, perkembangan teknologi informasi yang pesat membutuhkan pemuda-pemuda yang tanggap dan mampu menjadi agent of change di masyarakat. Pemuda tidak boleh hanyut terseret arus negatif globalisasi, pemuda harus berdiri kokoh menyangga sendi-sendi kehidupan dan bernegara di 
masyarakat. Pemuda memiliki idealisme, sikap kritis, dinamis, kreatif, inovatif dan memiliki energi yang besar bagi perubahan sosial dan cenderung masih murni dalam perjuangannya. Pemuda adalah modal sosial, agen perubahan dan pemegang kebijakan masa depan sebuah negara. Pemuda sebagai agen perubahan harus selalu bergerak untuk melakukan perubahan, di samping mempersiapkan diri dengan perangkat intelektual (Setiawan, 2009:72-73). Pada dasarnya peran pemuda sangat penting untuk mengantisipasi dampak negatif dari globalisasi, karena pemuda adalah agen penting untuk melakukan perubahan. Apabila berbicara tentang sejarah Indonesia, semua peristiwa atau kejadian besar yang terjadi di Indonesia dilakukan oleh pemuda. Misal pada peristiwa Kebangkitan Nasional tahun 1908, Sumpah Pemuda tahun 1928 dan Kemerdekaan Indonesia pada tahun 1945 serta Peristiwa yang kenal dengan Gerakan Reformasi tahun 1998. Para pemuda masa lalu mampu menunjukkan sikap bela negaranya terhadap bangsa Indonesia, sehingga tidak dipungkiri banyak masyarakat yang mengatakan bahwa sejarah Indonesia adalah sejarah pemuda.

Walaupun demikian, dewasa ini ada gejala pemuda di Indonesia saat ini sangat berbeda jauh dari gambaran ideal pemuda masa lalu. Saat ini banyak pemuda yang yang melakukan tindakan yang bertentangan dengan nilai-nilai Pancasila, seperti keterlibatan dalam penyalagunaan narkoba, tindak kekerasan, pencurian, seks bebas dan lain sebagainya. Pada dasarnya sikap bela negara para pemuda di era sekarang semakin pudar, karena banyak sikap dan tindakan pemuda Indonesia tidak mencerminkan sikap yang dimiliki para pemuda di zaman dahulu (sikap bela negara). Padahal tugas para pemuda di zaman dahulu (sebelum kemerdekaan) lebih berat dari pada pemuda zaman sekarang, zaman dahulu para pemuda berusaha untuk mengusir penjajah, sedangkan pemuda sekarang hanya diberi tugas untuk memelihara NKRI, namun yang terjadi saat ini adalah para pemuda tidak berusaha untuk mengisi dan memelihara kemerdekaan RI.

Fenomena tersebut menunjukkan bahwa sikap bela negara pemuda di Indonesia semakin luntur, yang langsung maupun tidak langsung pada akhirnya dapat berpengaruh pada tingkat ketahanan nasional. Pudarnya sikap bela negara secara langsung maupun tidak langsung akan mempengaruhi kehidupan masyarakat di bidang ideologi, politik, ekonomi, sosial dan budaya.

Untuk menumbuhkan sikap bela negara kepada para pemuda di Indonesia, maka diperlukan wadah atau organisasi kepemudaan yang selalu berusaha untuk menanamkan nilai-nilai bela negara dan nasionalisme. Melalui wadah tersebut, maka ketahanan wilayah yang tangguh di setiap daerah dapat terwujud. Organisasi Purna Paskibraka Indonesia (PPI) merupakan organisasi kepemudaan yang difungsikan untuk mewadahi para pemuda agar memiliki sikap bela negara. Purna Paskibraka Indonesia (PPI) sebagai perkumpulan pasukan pengibar bendera pusaka merupakan wadah bagi para pemuda untuk mengaktualisasikan dirinya. Di organisasi ini para pemuda ditempa, digembleng, dibina baik secara fisik maupun mental untuk menjadi pemuda yang tangguh, disiplin, dan berkarakter. Purna Paskibraka Indonesia (PPI) selalu berusaha untuk menanamkan nilai-nilai nasionalisme dan bela negara kepada para pemuda, sehingga 
Irwan, Muhamad Supraja, Ahmad Zubaidi -- Dinamika Aktualisasi Diri Pemuda Rantau Dan Implikasinya Terhadap Ketahanan Pribadi (Studi Pada Mahasiswa Rantau Asal Sumatra Barat Di Asrama Putri Bundo Kanduang Daerah Istimewa Yogyakarta)

melalui organisasi tersebut ketahanan wilayah yang tangguh di setiap daerah dapat terwujud.

Kabupaten Klaten merupakan Kabupaten yang membutuhkan peran organisasi Purna Paskibraka Indonesia (PPI) untuk membentuk pemuda yang memiliki jiwa nasionalisme dan bela negara. Purna Paskibraka Indonesia (PPI) Kabupaten Klaten memiliki tugas dan fungsi menciptakan ketahanan wilayah yang tangguh, sehingga dalam kegiatannya selalu melakukan pembinaan kepada para pemuda untuk memiliki jiwa bela negara yaitu melalui program pendidikan dan pelatihan.

Secara spesifik permasalahan yang diangkat dalam tulisan ini adalah (1) partisipasi pemuda Purna Paskibraka Indonesia (PPI) Kabupaten Klaten dalam kegiatan bela Negara, dan (2) pengaruh partisipasi pemuda Purna Paskibraka Indonesia (PPI) Kabupaten Klaten terhadap ketahanan wilayah di Kabupaten Klaten. Tujuan penulisan ini pada dasarnya untuk menganalisis partisipasi Purna Paskibraka Indonesia (PPI) Kabupaten Klaten dalam kegiatan bela negara, dan mengetahui pengaruh kegiatan bela negara yang dilakukan oleh pemuda Purna Paskibraka Indonesia (PPI) Kabupaten Klaten terhadap ketahanan wilayah di Kabupaten Klaten.

Jenis penelitian yang digunakan peneliti dalam penelitian ini adalah penelitian kualitatif. Menurut Strauss dan Corbin (2003:4) penelitian kualitatif merupakan jenis penelitian yang temuantemuannya tidak diperoleh melalui prosedur statistik atau bentuk hitungan lainnya. Penelitian kualitatif pada dasarnya memiliki tiga unsur utama, yaitu data bisa berasal dari bermacam sumber, biasanya dari wawancara dan pengamatan, prosedur analisis dan interpretasi yang digunakan untuk mendapatkan temuan, serta laporan tertulis dan lisan. Penelitian yang berlokasi di Kabupaten Klaten ini menggunakan beberapa teknik pengumpulan data, yaitu (1) observasi, dengan mengobservasi kegiatankegiatan yang dilakukan oleh Pemuda Purna Paskibraka Indonesia (PPI) Kabupaten Klaten, (2) indepth interview dengan jumlah narasumber 12 (dua belas orang), (3) studi pustaka, yang terdiri dari jurnal dan buku, (4) dokumentasi, yang berupa foto wawancara dan beberapa foto kegiatan yang dilakukan oleh Pemuda Purna Paskibraka Indonesia (PPI) Kabupaten Klaten, dan (5) Internet, yang difungsikan sebagai data sekunder. Analisis data dalam penulisan ini terdiri dari tiga alur yang terjadi secara bersamaan yaitu reduksi data, penyajian data kemudian penarikan kesimpulan.

\section{PEMBAHASAN}

\section{Gambaran Umum Kabupaten Klaten}

Kabupaten Klaten merupakan kota yang diapit oleh dua kota besar yaitu Yogyakarta dan Surakarta. Di sebelah utara Kabupaten Klaten berbatasan dengan Kabupaten Boyolali, di sebelah selatan berbatasan dengan Kabupaten Gunungkidul DIY, di sebelah barat berbatasan dengan Kabupaten Sleman DIY, dan di sebelah timur berbatasan dengan Kabupaten Sukoharjo. Dengan letak geografisnya yang strategis, yaitu berada di antara Kota Yogyakarta dan Kota Surakarta menjadikan Klaten sebagai kota yang memiliki karakteristik yang menarik untuk dikaji dan dicermati baik secara ekonomi, politik, maupun sosial budaya.

Jumlah Kecamatan yang berada di Kabupaten Klaten sejumlah 26 Kecamatan, kemudian terdiri dari 391 desa dan 10 
kelurahan. Berikut tabel 1 Luas Wilayah Kabupaten Klaten Berdasarkan Kecamatan.

Tabel 1

Luas Wilayah Kabupaten Klaten Berdasakan Kecamatan

\begin{tabular}{|c|c|c|c|c|}
\hline Kecamatan & Desa & Kelurahan & Dukuh & $\begin{array}{c}\text { Luas } \\
\text { Wilayah }\end{array}$ \\
\hline 01 Prambanan & 16 & - & 183 & 24,43 \\
\hline 02 Gantiwarno & 16 & - & 149 & 25,64 \\
\hline 03 Wedi & 19 & - & 178 & 24.58 \\
\hline 04 Bayat & 18 & - & 228 & 39.43 \\
\hline 05 Cawas & 20 & - & 238 & 34,47 \\
\hline 06 Trucuk & 18 & - & 171 & 33,81 \\
\hline 07 Kalikotes & 7 & - & 99 & 12,98 \\
\hline 08 Kebonarum & 7 & - & 65 & 9.67 \\
\hline 09 Jogonalan & 18 & - & 202 & 26.70 \\
\hline 10 Manisrenggo & 14 & - & 252 & 26,96 \\
\hline 11Karangnongko & 14 & - & 35 & 26,74 \\
\hline 12Ngawen & 13 & - & 124 & 16,97 \\
\hline 13 Caper & 18 & - & 42 & 24.45 \\
\hline 14 Pedan & 14 & - & 151 & 19,17 \\
\hline 15 Karangdowo & 19 & - & 161 & 29,23 \\
\hline 16 Juwiring & 19 & - & 208 & 29,79 \\
\hline 17. Wonosari & 18 & - & 149 & 31,14 \\
\hline 18 Delanggu & 18 & - & 37 & 18,78 \\
\hline 19 Polanharjo & 18 & - & 44 & 23,84 \\
\hline 20 Karanganom & 19 & - & 48 & 24,06 \\
\hline 21 Tulung & 18 & - & 185 & 32,00 \\
\hline 22 Jatinom & 17 & 1 & 207 & 35.53 \\
\hline 23 Kemalang & 13 & - & 214 & 51,66 \\
\hline 24 Klaten Selatan & 11 & 1 & 112 & 14.43 \\
\hline 25 Klaten Tengah & 5 & 6 & 97 & 8,92 \\
\hline 26 Klaten Utara & 6 & 2 & 124 & 10,38 \\
\hline Jumlah & 391 & 10 & 3.703 & 655,56 \\
\hline
\end{tabular}

Sumber: BPS Kabupaten Klaten Tahun 2014

Jumlah penduduk di Kabupaten Klaten dari tahun ke tahun selalu mengalami perubahan, karena banyak penduduk yang sering berpindah-pindah antar kota satu dengan kota yang lainnya. Berikut tabel 2 Jumlah Penduduk di Kabupaten Klaten dari tahun 2009-2014 berdasarkan jenis kelamin.

Jumlah penduduk di Kabupaten Klaten apabila dilihat berdasarkan jenis kelamin jumlahnya berimbang, karena perbedaan jumlah antara laki-laki dan perempuan tidak jauh berbeda.
Tabel 2.

Jumlah penduduk di Kabupaten Klaten Jumlah Penduduk Klaten

Tahun 2009-2014

Population in Klaten Regency 2009-2004

\begin{tabular}{cccc}
\hline $\begin{array}{c}\text { Tahun/ } \\
\text { Year } \\
(1)\end{array}$ & $\begin{array}{c}\text { Laki-laki/ } \\
\text { Male } \\
(2)\end{array}$ & $\begin{array}{c}\text { Perempuan/ } \\
\text { Female } \\
(3)\end{array}$ & $\begin{array}{c}\text { Jumlah/ } \\
\text { Total } \\
(4)\end{array}$ \\
\hline & & & \\
2014 & 556,449 & $587-591$ & 1.144 .040 \\
2013 & 546,335 & $670-572$ & 1.315 .907 \\
2012 & 644.362 & 669,552 & 1.515 .914 \\
2011 & 642.379 & 668,649 & 1.311 .019 \\
2010 & 640.187 & 567,575 & 1.307 .562 \\
2009 & 637.939 & 665.971 & 1.303 .910 \\
\hline
\end{tabular}

Sumber: BPS Kabupaten Klaten Tahun 2014

\section{Pemuda Purna Paskibraka Indonesia Kabupaten Klaten}

Paskibraka merupakan generasi muda yang mendapat kehormatan bertugas sebagai pengibar dan penurun bendera merah putih dalam rangka memperingati detik-detik proklamasi kemerdekaan Republik Indonesia. Asal mula Paskibraka tidak bisa lepas dari upacara pembacaan teks Proklamasi Kemerdekaan RI pada tanggal 17 Agustus 1945. Pada saat itulah bendera pusaka dikibarkan untuk kali pertama. Adapun yang mengibarkan bendera pada saat itu adalah Latief Hendraningrat, Trimurti, dan Suhud.

Para pemuda yang pernah bertugas sebagai Paskibraka baik di tingkat kabupaten, provinsi, maupun nasional tergabung dalam Purna Paskibraka Indonesia. Purna Paskibraka Indonesia (selanjutnya disebut PPI) merupakan bagian dari generasi muda Indonesia yang melakukan kegiatan dalam kerangka kehidupan berbangsa dan bernegara. Di Kabupaten Klaten organisasi PPI terbentuk pada tahun 2012. PPI Kabupaten Klaten dibentuk atas dasar keprihatinan bahwa mengapa setelah purna tugas pada upacara pengibaran bendera 17 Agusus tidak ada wadah dan kelanjutan kegiatan serta pembinaannya. 
Irwan, Muhamad Supraja, Ahmad Zubaidi -- Dinamika Aktualisasi Diri Pemuda Rantau Dan Implikasinya Terhadap Ketahanan Pribadi (Studi Pada Mahasiswa Rantau Asal Sumatra Barat Di Asrama Putri Bundo Kanduang Daerah Istimewa Yogyakarta)

Gagasan untuk mendirikan organisasi PPI di Kabupaten Klaten telah dimulai sejak tahun 2007. Pada waktu itu Paskibraka yang bertugas di tingkat kabupaten masih menggunakan sistem penunjukan langsung ke sekolah oleh Dinas Kebudayaan, Pariwisata, Pemuda dan Olahraga Kabupaten Klaten. Misal pada tahun 2007 yang bertugas dari SMA N 1 Klaten, tahun berikutnya yang bertugas adalah SMAN 2 Klaten, tahun berikutnya SMA N 3 Klaten, dan seterusnya. Pada masa itu sekolah yang memiliki organisasi Paskibraka hanyalah SMA N 1 Klaten, SMA N 2 Klaten, SMA N 3 Klaten, SMA N 1 Karanganom, dan SMA N 1 Wonosari sehingga pilihannya terbatas dan kualitas yang dihasilkan pun hanya dalam batas standar minimal karena dilakukan penunjukan secara langsung, tidak dilakukan seleksi secara terbuka.

Atas dasar keprihatinan dan juga keinginan dari para Purna Paskibraka tingkat Kabupaten Klaten untuk memajukan dunia Paskibraka di Kabupaten Klaten, maka pada tahun 2011 Naufan Azim Haridistya bersama dengan rekan-rekan perwakilan dari SMAN 1 Klaten, SMA N 2 Klaten dan SMA N 3 Klaten mengadakan pertemuan untuk membahas pembentukan organisasi PPI Kabupaten Klaten. Pertemuan tersebut berlangsung setelah pengibaran bendera 17 Agustus 2011. Pertemuan demi pertemuan berlangsung intensif, mematangkan ide dan konsep organisasi, berkoordinasi dengan Pengurus PPI Provinsi Jawa Tengah, serta melakukan konsultasi dengan Dinas Kebudayaan, Pariwisata, Pemuda dan Olahraga Kabupaten Klaten selaku Pembina. Setelah pertemuan demi pertemuan terlaksana, pada bulan Februari 2012 diadakanlah Musyawarah Cabang Tingkat Kabupaten untuk yang pertama kalinya.
Bentuk Partisipasi dalam Kegiatan Bela Negara

Purna Paskibraka Indonesia (PPI) sebagai organisasi kemasyarakatan yang memiliki tujuan untuk membentuk manusia Indonesia yang berjiwa Pancasila serta patuh dan taat kepada Negara Kesatuan Republik Indonesia melakukan berbagai kegiatan dalam rangka mencapai tujuannya. Kegiatan yang dilakukan oleh PPI Kabupaten Klaten akan diklasifikasikan menjadi empat model kegiatan, yaitu model kegiatan yang bersifat ideologis, model kegiatan yang bersifat interaksi sosial, model kegiatan kompetisi antar Paskibra, dan model kegiatan yang bersifat aksi. Empat model kegiatan ini merupakan bentuk partisipasi pemuda Purna Paskibraka Indonesia dalam rangka bela negara. Keempat model ini merupakan penjabaran dari penanaman nilai kehidupan berbangsa dan bernegara.

Pertama, kegiatan bersifat ideologis. Kegiatan bersifat ideologis yang dilakukan oleh Purna Paskibraka Indonesia Kabupaten Klaten adalah rangkaian kegiatan Upacara Bendera 17 Agustus. Bagi Paskibraka, upacara 17 Agustus adalah suatu momen yang sakral. Pada upacara tersebut, semua pandangan mata akan tertuju pada Paskibraka. Sang Merah Putih yang berkibar menjadi saksi perjuangan para pahlawan Indonesia yang rela berkorban demi berdirinya NKRI dan berkibarnya bendera merah putih.

Di Kabupaten Klaten setiap tahun diadakan upacara peringatan Hari Kemerdekaan Republik Indonesia pada tanggal 17 Agustus. Kabupaten Klaten selalu mengirimkan delegasinya untuk mengikuti seleksi Paskibraka tingkat Provinsi dan juga terkadang anggota Paskibraka Kabupaten Klaten terpilih menjadi anggota Paskibraka 
di tingkat Nasional. Proses seleksi yang dilakukan oleh Purna Paskibraka Indonesia Kabupaten Klaten merupakan proses pelatihan untuk mendorong munculnya sikap bela negara dan pantang menyerah para pemuda. Melalui kegiatan ini, yang terpilih menjadi anggota Purna Paskibraka Indonesia Kabupaten Klaten akan diseleksi kembali untuk menemukan beberapa pemuda yang akan didelegasikan mewakili Kabupaten Klaten untuk mengikuti seleksi anggota Paskibraka tingkat provinsi.

Agar anggota Paskibraka Kabupaten Klaten selalu ikut serta menjadi anggota Paskibraka tingkat provinsi dan pusat, maka Purna Paskibraka Indonesia Kabupaten Klaten selalu mengadakan rangkaian kegiatan untuk memilih/menyeleksi para pemuda di daerah Kabupaten Klaten. Kegiatan tersebut pada dasarnya adalah kegiatan untuk mendorong para pemuda untuk berkompetisi dan menanamkan sikap nasionalisme para pemuda, Rangkaian kegiatan dalam rangka upacara bendera 17 Agustus dibagi menjadi enam kegiatan yaitu (1) Seleksi, (2) Pendidikan dan latihan, (3) Pengukuhan, (4) Pengibaran Bendera, (5) Penurunan Bendera, dan (6) Pelantikan.

Rangkaian kegiatan dalam rangka upacara bendera 17 Agustus merupakan suatu rangkaian untuk menanamkan nilai-nilai bela negara, karena para anggota akan mendapatkan pemahaman tentang indikator-indikator bela negara, kemudian para anggota dituntut untuk mengaplikasikan pengetahuan yang sudah diperoleh. Pada dasarnya proses seleksi untuk menjadi anggota Purna Paskibraka Indonesia Kabupaten Klaten adalah bentuk gerakan untuk selalu mendorong para pemuda di Kabupaten Klaten untuk memiliki sikap bela negara dan juga selalu mendorong para pemuda untuk berpartisipasi dalam bela negara.
Kedua, kegiatan bersifat interaksi sosial. Kegiatan bersifat interaksi sosial yang dilakukan oleh Purna Paskibraka Indonesia Kabupaten Klaten adalah menyelenggarakan acara Parade Universitas. Acara Parade Universitas ini diadakan pada hari Sabtu dan Minggu tanggal 31 Januari - 1 Februari 2015. Acara ini diberi nama Parade Universitas karena acara ini adalah rangkaian dari berbagai macam kegiatan dan pelaksanaannya dilakukan melalui kerjasama dengan beberapa universitas. Ada 4 (empat) kegiatan dalam acara Parade Universitas ini, yaitu:

(1) Sosialisasi Perguruan Tinggi. Sosialisasi perguruan tinggi ini bertujuan untuk memberikan informasi dan gambaran tentang jurusan dan program studi yang ada di masing-masing universitas. Kegiatan ini juga memberikan tips bagaimana agar bisa diterima di perguruan tinggi tersebut, sekaligus memberikan gambaran tentang kehidupan di kota di mana perguruan tinggi tersebut berada. Kegiatan sosialisasi Perguruan Tinggi ini Purna Paskibraka Indonesia Kabupaten Klaten bekerjasama dengan Universitas Gadjah Mada, Universitas Indonesia, Universitas Teknologi Telkom, Universitas Diponegoro, dan Universitas Negeri Sebelas Maret.

Kegiatan Sosialisasi ini dilakukan oleh Purna Paskibraka Indonesia Kabupaten Klaten dengan mengundang beberapa mahasiswa yang aktif dalam kegiatan sosial (aktivis) di kampusnya untuk memperomosikan kampusnya masing-masingnya dan juga mengundang beberapa dosen dari beberapa universitas untuk mempresentasikan materi tentang kehidupan di kampus. Kegiatan ini sangat diapresiasi oleh para peserta dan para peserta sangat antusias dalam mengikuti kegiatan ini, karena sesuai dengan kebutuhan para peserta akan informasi seputar dunia kampus. 
Irwan, Muhamad Supraja, Ahmad Zubaidi -- Dinamika Aktualisasi Diri Pemuda Rantau Dan Implikasinya Terhadap Ketahanan Pribadi (Studi Pada Mahasiswa Rantau Asal Sumatra Barat Di Asrama Putri Bundo Kanduang Daerah Istimewa Yogyakarta)

(2) Seminar Character Building. Seminar character building ini menghadirkan Reza Amaludin, mahasiswa UGM yang berasal dari Klaten yang juga seorang pengusaha muda dan aktivis sosial lewat komunitasnya yang bernama Students Care. Acara ini bertujuan untuk menggugah semangat para peserta yang terdiri dari generasi muda untuk lebih giat berprestasi dan lebih giat berkarya, dengan menghadirkan seorang yang mampu menjalani peran sebagai mahasiswa berprestasi, aktivis sosial, sekaligus pengusaha di usia yang masih muda harapannya para peserta mampu termotivasi dan menjadi generasi muda yang kreatif, unggul, mandiri, dan berprestasi.

Kegiatan ini sangat diapresiasi oleh para peserta karena sangat menginspirasi para peserta untuk tidak mudah putus asa, selain itu para peserta juga termotivasi untuk menjadi seorang aktivis, karena memiliki anggapan bahwa seorang pengusaha harus diawali dengan aktif menggeluti di berbagai macam bidang khususnya bidang sosial.

(3) Lomba Cerdas Cermat Wawasan Kebangsaan. Lomba Cerdas Cermat Wawasan Kebangsaan ini diadakan untuk mengasah pengetahuan generasi muda tentang Pancasila dan Kehidupan Berbangsa dan Bernegara. Materi yang dilombakan dalam lomba ini adalah tentang Pancasila dan UUD 1945, akan tetapi acara ini urung terlaksana karena jumlah pesertanya minim, hingga dengan pelaksanaan acara hanya ada 1 (satu) sekolah yang mendaftar. Pada dasarnya kegiatan ini sangat efektif untuk membina pengetahuan tentang nasionalisme para pemuda khususnya yang sedang dudu di bangku SMA, namun antusias sekolah di Kabupaten Klaten untuk mendelegasikan siswanya untuk mengikuti kegiatan ini masih sangat kurang.
(4) Talkshow Inspiratif dengan tema "Do More Get Your Dream". Acara talkshow ini merupakan puncak dari rangkaian kegiatan Parade Universitas. Talkshow ini menghadirkan dua orang pembicara yang juga tokoh nasional yaitu Gubernur Jawa Tengah Ganjar Pranowo, dan Ketua Ombudsman Republik Indonesia Danang Girindrawardana. Ide untuk menghadirkan Ganjar Pranowo dan Danang Girindrawardana adalah karena keduanya merupakan sosok yang masih muda namun mampu menjadi tokoh nasional dan memegang amanah yang besar. Ganjar Pranowo berhasil menjadi Gubernur di usia yang masih relatif muda. Sosoknya yang mantan aktivis mahasiswa diharapkan mampu memotivasi generasi muda untuk peduli dan kritis terhadap situasi di sekitarnya. Begitu pula dengan sosok Danang Girindrawardana, ia memimpin sebuah lembaga tingkat nasional yaitu Ombudsman RI di usia yang juga masih muda. Dengan hadirnya kedua sosok ini dalam acara talkshow inspiratif Parade Universitas diharapkan akan mampu menginspirasi generasi muda untuk senantiasa berani menjawab tantangan dan tuntutan jaman.

Kegiatan Parade Universitas ini, selain menjadi ajang untuk mencari dan berbagi ilmu juga sebagai sarana untuk menjalin dan memperluas relasi (channeling). Para peserta dapat menjalin relasi dengan narasumber acara, dan juga menjalin relasi dengan sesama peserta. Dengan menjalin dan memperluas relasi di antara peserta akan tercipta jaringan antara masyarakat dengan Purna Paskibraka Indonesia Kabupaten Klaten sehingga perannya akan dirasakan secara nyata oleh masyarakat.

Ketiga, kegiatan kompetisi antar Paskibra. Purna Paskibraka Indonesia Kabupaten Klaten memiliki agenda rutin tahunan yaitu mengadakan 
Lomba Peraturan Baris Berbaris (LPBB) tingkat Kabupaten Klaten yang diberi nama LPBB PPI Bersinar. Pemberian nama tersebut terinspirasi dari slogan Kabupaten Klaten yaitu 'BERSINAR" yang merupakan akronim dari Bersih, Sehat, Indah, Nyaman, Aman, Rapi. LPBB PPI Bersinar ini diadakan rutin setiap satu tahun sekali bekerjasama dengan Dinas Pariwisata, Kebudayaan, Pemuda dan Olahraga Kabupaten Klaten, selain memperebutkan gelar juara tingkat kabupaten, kegiatan ini juga merupakan event resmi yang merupakan seleksi Peleton Paskibraka tingkat SMA/SMK tingkat Kabupaten Klaten untuk mengirimkan wakilnya ke perlombaan di tingkat yang lebih tinggi, yaitu LPBB tingkat Karesidenan Surakarta dan LPBB tingkat Provinsi Jawa Tengah. LPBB PPI Bersinar ini dilaksanakan dengan maksud dan tujuan (1) Meningkatkan kedisiplinan, kesehatan jasmani, dan rohani serta kreativitas di kalangan siswa SMP sederajat dan siswa SMA sederajat, (2) Memperdalam rasa cinta tanah air serta mempertebal semangat kebangsaan dan kesatuan di kalangan siswa SMP dan siswa SMA sederajat, (3) Menumbuhkan rasa dinamisme, sportif, kreatif, dan inovatif dalam bidang tata upacara bendera dan baris berbaris, (4) Meningkatkan rasa persatuan dan kesatuan serta kedisiplinan siswa melalui tata upacara bendera dan baris berbaris, (5) Meningkatkan kualitas dan kuantitas tata upacara bendera dan baris berbaris di sekolah, (6) Mempersiapkan peserta untuk lomba tata upacara bendera dan baris berbaris tingkat Kabupaten Klaten (Pemerintah Kabupaten Klaten, 2016).

LPBB PPI Bersinar ini telah diadakan tiga kali, yaitu pada tahun 2013. 2014, dan 2015. Pada LPBB PPI Bersinar 2015, pelaksanaannya dilakukan pada 19 Desember 2015 dimana pada hari itu bertepatan dengan Hari Bela Negara. Dari tiga kali pelaksanaan,
LPBB PPI Bersinar mampu menarik animo dan antusiasme peserta maupun penonton. Hal ini terlihat dari tribun di area tempat pelaksanaan kegiatan yang ramai dipadati oleh penonton.

LPBB PPI Bersinar III diikuti oleh 19 peleton dari 14 SMA/SMK se Kabupaten Klaten, dan 8 peleton dari 6 SMP se Kabupaten Klaten. Perlombaan dibagi menjadi dua pos. Pos pertama yaitu gerakan dasar, dibagi lagi menjadi dua sesi. Sesi pertama yaitu GDD atau Gerakan Dasar Di Tempat. Sesi ini memperlombakan gerakan dasar seperti sikap sempurna, sikap istirahat di tempat, hadap kanan, hadap kiri, hadap serong kanan, hadap serong kiri. Kemudian sesi kedua yaitu GDB atau Gerakan Dasar Berjalan. Gerakan Dasar Berjalan ini memperlombakan gerakan dasar dengan posisi berjalan seperti gerakan jalan di tempat, langkah tegap, belok kanan, belok kiri, melintang kanan dan melintang kiri. Untuk pos kedua, yaitu pos GVF atau Gerakan Variasi dan Formasi. Untuk pos ini merupakan sesi yang menarik dan paling ditunggu-tunggu oleh para penonton. Pada pos Gerakan Variasi dan Formasi, tiap-tiap peleton peserta dipersilakan untuk membuat gerakan formasi barisan sesuai dan variasi gerakan sesuai dengan kreativitas.

Gerakan Variasi dan Formasi ini merupakan perpaduan antara kreativitas dan olah jasmani karena memadukan antara gerakan-gerakan dasar yang ada dalam Peraturan Baris Berbaris kemudian diberi kreasi menjadi sebuah gerakan yang atraktif dan variatif. Gerakan ini juga dipadu dengan yel-yel dari masing-masing peleton. Yel-yel ini merupakan ekspresi perwujudan cinta tanah air karena kata-kata yang dipakai bertemakan nasionalisme dan biasanya dipadu dengan ciri khas dari sekolah masing-masing. Perpaduan antara gerakan variasi formasi dan yel-yel ini 
menunjukkan bahwa dalam setiap gerakan yang diajarkan dalam Paskibraka memiliki makna terhadap nasionalisme.

LPBB PPI Bersinar yang telah diadakan tiga kali mampu menarik perhatian sekolahsekolah yang ada di Kabupaten Klaten. Lomba ini menjadi ajang untuk meningkatkan semangat dalam bidang Peraturan Baris Berbaris dan juga untuk mengasah jiwa bersaing yang sehat. LPBB PPI Bersinar juga menjadi ajang bagi masing-masing sekolah untuk menunjukkan prestasinya. Selepas selesai bertugas pada upacara 17 Agustus, Paskibraka masing-masing sekolah dipersiapkan untuk menghadapi lombalomba Peraturan Baris Berbaris yang ada dan puncaknya adalah di LPBB PPI Bersinar. Semenjak terbentuknya Purna Paskibraka Indonesia, perwakilan dari Kabupaten Klaten selalu menorehkan prestasi menjadi pembawa baki di Upacara Peringatan 17 Agustus tingkat Provinsi Jawa Tengah. Prestasi itu makin meningkat ketika pada tahun 2015 perwakilan dari Kabupaten Klaten berhasil meloloskan wakilnya ke Paskibraka Nasional. Untuk itulah kegiatan Lomba PBB ini terus diadakan.

Keempat, kegiatan bersifat aksi. Purna Paskibraka Indonesia Kabupaten Klaten juga mengadakan kegiatan berupa aksi. Kegiatan itu adalah "Sebar Pita di Car Free Day Dalam Rangka Memperingati Hari Kebangkitan Nasional". Memanfaatkan momen Hari Kebangkitan Nasional, Purna Paskibraka Indonesia Kabupaten Klaten mengadakan aksi simpatik di sepanjang area Car Free Day Klaten. Kegiatan ini berupa membagikan sekaligus menyematkan pita berwarna merah putih yang telah diberi tulisan "Purna Paskibraka Kabupaten Klaten" kepada masyarakat yang sedang berada di area Car Free Day. Kegiatan ini bertujuan untuk ikut menyemarakkan peringatan Hari Kebangkitan Nasional sekaligus sebagai aksi untuk menunjukkan eksistensi Purna Paskibraka Indonesia Kabupaten Klaten di tengah-tengah masyarakat. Pita berwarna merah putih melambangkan perwujudan nasionalisme. Dengan menyematkan pita kepada masyarakat, Purna Paskibraka Indonesia Kabupaten Klaten berharap bahwa semangat kebangkitan nasional mampu diresapi dan dihayati dengan baik oleh masyarakat di semua lapisan.

Kegiatan lain yang dilakukan Purna Paskibraka Indonesia Kabupaten Klaten yang bersifat aksi adalah menjadi petugas pembawa bendera negara-negara peserta pada penutupan perhelatan WMPC (World Military Parachuting Championship). WMPC ini adalah Kejuaraan Terjun Payung Militer Internasional. Acara yang dimulai pada tanggal 18 September ini dibuka di Solo, Jawa Tengah dan ditutup pada 26 September 2014 di Candi Prambanan. Diawali dengan kirab budaya di Solo, rangkaian kejuaraan WMPC ini ditutup dengan atraksi terjun payung di area Candi Prambanan. Pada upacara penutupan, Purna Paskibraka Indonesia Kabupaten Klaten bertugas untuk menjadi pembawa bendera negara-negara yang ikut serta pada kejuaraan WMPC.

\section{Pemahaman Terhadap Bela Negara}

Relasi antara negara dengan warga negara merupakan suatu bentuk relasi yang saling berkaitan. Negara dan warga negara memiliki peranan dan fungsi masing-masing di dalam kehidupan sosial. Warga negara membutuhkan kehadiran negara untuk menjamin hak-hak hidupnya agar hak sebagai warga negara dapat tertunaikan dengan baik, selain itu negara juga membutuhkan pembelaan dari warga negaranya. Negara membutuhkan kehadiran warga negaranya untuk kepentingan menjaga 
eksistensi negara dan juga sebagai subyek sekaligus obyek dalam rangka mencapai tujuannya. Warga negara memiliki peran penting dalam menjaga keutuhan negara dan eksistensi negara.

Relasi antara negara dan warga negara dalam konteks kehidupan berbangsa dan bernegara harus berjalan seimbang. Keduanya harus memiliki pemahaman dan kesadaran akan hak dan kewajibannya masing-masing. Sesuai dengan yang tercantum dalam Pasal 30 UUD 1945, warga negara memiliki hak dan kewajiban untuk melakukan kegiatan bela negara. Kegiatan yang memiliki tujuan untuk meningkatkan rasa nasionalisme dan patriotisme harus diikuti oleh setiap warga negara terutama para generasi muda. Cinta tanah air merupakan perwujudan dari semangat patriotisme dan nasionalisme, oleh sebab itu ketiganya mempunyai hubungan erat yang tidak terpisahkan. Mengorbankan diri demi kemerdekaan adalah transendental, sehingga pemuda berebut untuk berjuang dan rela berkorban. Keagungan berjuang yang diperebutkan inilah kemudian menjadikan bela negara diberikan kepada warga negara sebagai hak. Namun sebaliknya bela negara adalah kewajiban bagi warga negara, sebagai imbal balik atas layanan negara terhadap warganya (Siswanto, 2013: 123). Di masa yang akan datang, tantangan dan ancaman yang dihadapi oleh negara akan semakin berat dan bervariasi. Oleh karena itu, para generasi muda harus memiliki pemahaman dan kesadaran terhadap kegiatan bela negara.

Pada uraian sebelumnya telah dijelaskan bahwa para pemuda yang tergabung dalam Purna Paskibraka Indonesia Kabupaten Klaten melakukan berbagai kegiatan dan aksi dalam rangka kegiatan bela negara. Kegiatan-kegiatan tersebut dilakukan untuk memberikan pemahaman tentang bela negara kepada para anggotanya dan juga kepada masyarakat. Menurut Winkel dan Mukhtar (Sudaryono, 2012: 44), pemahaman adalah kemampuan seseorang untuk menangkap makna dan arti dari bahan yang dipelajari, yang dinyatakan dengan menguraikan isi pokok dari suatu bacaan atau mengubah data yang disajikan dalam bentuk tertentu ke bentuk yang lain. Sementara Benjamin S. Bloom (Sudijono, 2009: 50) mengatakan bahwa pemahaman (comprehension) adalah kemampuan seseorang untuk mengerti atau memahami sesuatu setelah sesuatu itu diketahui dan diingat. Dengan kata lain, memahami adalah mengerti tentang sesuatu dan dapat melihatnya dari berbagai segi. Berdasarkan temuan penelitian, pemahaman pemuda Purna Paskibraka Indonesia terhadap kewajiban bela negara dilakukan melalui dua hal, yaitu melalui Tata Upacara Bendera dan Peraturan Baris Berbaris. Kegiatan di Paskibraka dibagi menjadi dua yaitu TUB (Tata Upacara Bendera) dan PBB (Peraturan Baris Berbaris). Pada setiap kegiatan baik TUB mupun PBB memiliki kekhasan tertentu yang ditunjukkan lewat gerakan dan materimateri yang diajarkan pada saat pendidikan dan pelatihan.

Pada kegiatan TUB, penanaman nilainilai kebangsaan melalui upacara bendera, terutama pada saat momen upacara peringatan hari kemerdekaan Republik Indonesia. Nilai-nilai ini didapatkan ketika mereka menjalani pendidikan dan pelatihan serta pada prosesi pelaksanaan upacara bendera berlangsung. Rangkaian pendidikan dan pelatihan hingga prosesi pelaksanaan upacara bendera yang terdiri dari pelatihan fisik dan mental memberikan pengaruh bagi karakter mereka. Pelatihan fisik membentuk jasmani 
semakin kuat, sedangkan pelatihan mental membentuk karakter mereka menjadi tangguh.

Pada kegiatan PBB, penanaman nilainilai kebangsaan melalui gerakan-gerakan yang diajarkan baik gerakan dasar, gerakan berjalan, maupun gerakan variasi formasi. Gerakan-gerakan PBB yang diajarkan di Paskibraka mengandung nilai dan makna tentang kehidupan berbangsa dan bernegara. Gerakan-gerakan tersebut meliputi gerakan hormat bendera, gerakan sikap sempurna, barisan lurus, yel-yel, dan hukuman.

Gerakan hormat bendera. Gerakan ini bermakna penghormatan terhadap bangsa dan negara Indonesia. Hormat bendera merupakan sebuah sikap menghormati dan menghargai perjuangan para pendahulu bangsa, serta pengakuan terhadap negara dan pemerintahan yang sah. Gerakan ini menimbulkan rasa kebanggaan bagi anggota Paskibraka. Bagi anggota Paskibraka, gerakan hormat bendera mampu meningkatkan rasa cinta kepada Indonesia dan juga memberikan pengaruh pada sikap dan perilaku mereka sehari-hari.

Gerakan sikap sempurna. Gerakan ini bermakna siap bela negara. Sikap sempurna yang ditunjukkan dengan cara berdiri tegap, pandangan lurus ke depan, dada dibusungkan memberikan makna bahwa Paskibraka sebagai anak bangsa siap melaksanakan apa yang diminta oleh negara dan rela berkorban untuk kepentingan bangsa dan negara. Kemudian di dalam Paskibraka, barisan pun harus lurus. Lurusnya barisan merupakan perwujudan dari nilai persatuan dan kesatuan. Meskipun anggota Paskibraka berasal dari latar belakang anggota yang beragam, ketika berada dalam barisan mereka adalah satu kesatuan yang utuh dimana barisan harus lurus dan gerakan yang dilakukan harus sama dan serempak. Barisan lurus ini memiliki makna bahwa Indonesia yang terdiri dari berbagai macam suku, agama, dan ras harus bersatu. Ketika berada dalam koridor sebagai bangsa Indonesia maka nilai yang dibawa adalah nilai-nilai dan konsensus yang telah disepakati bersama.

Di Paskibraka juga diajarkan variasi materi baris berbaris. Salah satu variasi materi baris-berbaris yang diajarkan kepada para anggota Paskibraka adalah yel-yel. Yel-yel merupakan senandung yang berisi kata-kata pembakar semangat, diikuti dengan gerakan badan ketika menyanyikan yel-yel tersebut. Yel-yel ini merupakan perwujudan dari semangat membela tanah air. Pada waktu observasi di Lomba Baris Berbaris (LBB) PPI Bersinar III di GOR Gelarsena pada 19 Desember 2015, setiap peleton yang tampil selalu meneriakkan yel-yel mereka. Yel-yel ini diteriakkan ketika masuk ke dalam stage tempat arena lomba, dan ketika sesi gerakan variasi formasi. Kata-kata dalam yel-yel menggunakan kata yang menggugah semangat dipadu dengan kata yang menggugah rasa nasionalisme.

Di dalam barisan Paskibraka tentunya tidak terlepas dari adanya kesalahan baik ketika latihan maupun ketika menjalankan tugas di upacara bendera. Kesalahan yang dilakukan oleh anggota Paskibraka ketika berada di dalam barisan diganjar dengan hukuman fisik berupa push up. Hukuman yang diberikan ini bukan dimaksudkan untuk menyiksa atau melakukan kekerasan, namun lebih kepada penyadaran dan pembinaan terhadap anggota Paskibraka. Hukuman di dalam Paskibraka pun memiliki ciri yang khas. Jika ada salah satu anggota pasukan yang dihukum, maka seluruh anggota dalam pasukan tersebut juga mendapatkan hukuman yang serupa. Dari sini dapat dilihat bahwa hukuman di dalam Paskibraka merupakan 
perwujudan dari rasa kebersamaan dalam keberagaman. Paskibraka yang terdiri dari beragam latar belakang, ketika salah satu anggota pasukan mendapatkan hukuman maka yang lain pun ikut merasakan hukuman yang sama. Hal ini bermakna bahwa para anggota Paskibraka harus memiliki cara pandang yang satu sebagai masyarakat Indonesia. Ketika saudara sebangsa dan setanah air yang berada di daerah tertinggal dan terbelakang mengalami diskriminasi hak baik materiil maupun non materiil, maka masyarakat yang berada di daerah maju dan berkembang memiliki semangat untuk membela dan memiliki kepedulian untuk membantu.

\section{Kesadaran Terhadap Bela Negara}

Sebuah organisasi akan terus eksis dan berkembang ketika para anggotanya memiliki kesadaran terhadap peran yang dimilikinya. Kesadaran dan eksistensi suatu organisasi memiliki hubungan yang erat. Begitu pula dalam konteks kehidupan berbangsa dan bernegara. Warga negara yang memiliki kesadaran terhadap bela negara akan membuat negara memiliki ketahanan nasional yang kuat. Kesadaran muncul setelah seseorang memiliki pemahaman terhadap sesuatu. Setelah memahami nilai-nilai yang ada di dalam kehidupan berbangsa dan bernegara maka berikutnya akan muncul kesadaran di dalam diri setiap orang. Kesadaran terhadap kewajiban bela negara ditunjukkan oleh Purna Paskibraka Indonesia Kabupaten Klaten. Kesadaran tersebut ditunjukkan lewat empat hal yaitu (1) Ikut terlibat dalam kegiatan Purna Paskibraka Indonesia Kabupaten Klaten di tengah kesibukan sebagai pelajar, (2) Membina Organisasi Paskibra di sekolah masing-masing, (3) Menjaga lingkungan sekitar dari pengaruh negatif, (4) Patuh dan taat terhadap hak dan kewajiban sebagai warga negara.

\section{Komitmen Terhadap Bela Negara}

Komitmen adalah kemampuan dan kemauan untuk menyelaraskan perilaku pribadi dengan kebutuhan, prioritas dan tujuan organisasi. Hal ini mencakup caracara mengembangkan tujuan atau memenuhi kebutuhan organisasi yang intinya mendahulukan misi organisasi dari pada kepentingan pribadi (Soekidjan, 2009). Menurut Meyer dan Allen, komitmen dapat juga berarti penerimaan yang kuat individu terhadap tujuan dan nilai-nilai organisasi, dan individu berupaya serta berkarya dan memiliki hasrat yang kuat untuk tetap bertahan di organisasi tersebut (Soekidjan, 2009).

Sebagai seorang yang mendapatkan pendidikan dan latihan di Paskibraka, para anggota Purna Paskibraka Indonesia Kabupaten Klaten menyatakan komitmennya terhadap bela negara. Setelah memiliki pemahaman dan kesadaran terhadap bela negara, anggota Purna Paskibraka Indonesia Kabupaten Klaten menunjukkannya lewat komitmen sebagai berikut: (1) Para anggota Purna Paskibraka Indonesia Kabupaten Klaten ini ingin berbuat sesuatu untuk Indonesia dengan caranya masing-masing. Berkaca dari kondisi negara yang hari ini sedang mengalami berbagai macam problematika dalam berbagai sektor seperti sektor pendidikan, kesehatan, ekonomi, dan politik, para anggota Purna Paskibraka Indonesia Kabupaten Klaten menyatakan bahwa mereka ingin berbuat sesuatu untuk memajukan bangsa Indonesia. (2 Siap jika diminta untuk berperang, membela negara dari agresi militer maupun non militer. Kesiapan dan komitmen untuk bela negara 
Irwan, Muhamad Supraja, Ahmad Zubaidi -- Dinamika Aktualisasi Diri Pemuda Rantau Dan Implikasinya Terhadap Ketahanan Pribadi (Studi Pada Mahasiswa Rantau Asal Sumatra Barat Di Asrama Putri Bundo Kanduang Daerah Istimewa Yogyakarta)

tidak hanya ditunjukkan lewat kegiatan saja, namun juga kesiapan untuk mengangkat senjata apabila memang diperlukan. Hal ini menunjukkan bahwa para anggota Purna Paskibraka Kabupaten Klaten memiliki kesiapan dalam membela bangsa Indonesia dari berbagai ancaman. (3) Sistem seleksi Paskibraka yang semakin diperketat dari tahun ke tahun. Semenjak terbentuk Purna Paskibraka Indonesia Kabupaten Klaten pada tahun 2012, sistem seleksi Paskibraka di Kabupaten Klaten lebih terstruktur dengan baik. Tidak ada lagi sekolah yang mendominasi pasukan, semuanya memiliki kesempatan yang sama asalkan memiliki kemampuan dan kapasitas untuk menjadi Paskibraka. Berkaca dari pengalaman tersebut, pada tahun 2016 sistem seleksi akan lebih diperketat. Sesuai dengan hasil Rapat Kerja Kabupaten (Rakerkab) PPI Kabupaten Klaten 2016 yang diselenggarakan pada 28 Februari 2016, sistem seleksi pada tahun 2016 akan menggunakan sistem kewilayahan. Sebelum masuk seleksi tingkat Kabupaten terlebih dahulu akan diadakan seleksi tingkat wilayah. Hal ini menunjukkan bahwa Purna Paskibraka Indonesia Kabupaten Klaten secara organisasi memiliki komitmen untuk meningkatkan kualitas Paskibraka. (4) Merencanakan kegiatan PPI Kabupaten Klaten yang semakin banyak dan semakin bervariasi. Untuk lebih meningkatkan partisipasi anggota Purna Paskibraka Indonesia dalam kegiatan bela negara khususnya di Kabupaten Klaten, Purna Paskibraka Indonesia Kabupaten Klaten telah menyusun rencana program yang akan dilaksanakan pada tahun 2016 di mana program-program tersebut direncanakan akan lebih bervariasi dan lebih bermanfaat kepada masyarakat luas.

\section{Pengaruhna Terhadap Ketahanan Wilayah}

Hasil temuan penelitian menunjukkan bahwa partisipasi pemuda PPI dalam bela negara menghasilkan pemahaman, kesadaran, dan komitmen terhadap bela negara. Dari pemahaman, kesadaran, dan komitmen terhadap bela negara tersebut kemudian memberikan pengaruh terhadap ketahanan wilayah di Kabupaten Klaten. Pengaruh tersebut dilihat melalui delapan aspek ketahanan nasional, yaitu aspek geografi, aspek demografi, dan aspek sumber kekayaan alam yang merupakan tri gatra, serta aspek ideologi, aspek politik, aspek ekonomi, aspek sosial budaya, aspek pertahanan dan keamanan yang merupakan pancagatra.

Pengaruh ketahanan wilayah Kabupaten Klaten dari partisipasi pemuda PPI dalam bela negara secara langsung berpengaruh terhadap pancagatra (gatra sosial), sedangkan pada trigatra (gatra alamiah) tidak memiliki pengaruh secara langsung. Pengaruh terhadap aspek dari trigatra terlihat pada aspek demografi. Dari pendidikan, pelatihan, serta kegiatan yang dilakukan oleh PPI Kabupaten Klaten menghasilkan output berupa pemuda yang berkualitas unggul dan pemuda yang memiliki pengetahuan tentang nilai-nilai berbangsa dan bernegara. Output ini meningkatkan kualitas sumber daya manusia di Kabupaten Klaten. Dengan meningkatnya kualitas sumber daya manusia pemuda di Kabupaten Klaten, maka akan meningkatkan ketahanan wilayah Kabupaten Klaten.

\section{Keyakinan Terhadap Pancasila Sebagai Ideologi Bangsa}

Menurut Kodiran (2006) ideologi merupakan bentuk yang digunakan untuk melakukan pembenaran terhadap tatanan 
sosial tertentu dan tatanan yang terjadi itu merupakan tatanan yang sudah ada dan dilestarikan, dari tatanan sosial ini membentuk sebuah keyakinan yang ada dalam setiap diri manusia untuk menjadi pedoman hidupnya sehari-hari. Pada aspek ideologi, pengaruhnya terlihat pada dua hal. Pertama, yakin terhadap Pancasila sebagai ideologi bangsa. Dengan memiliki keyakinan terhadap ideologi bangsa, maka pemuda-pemuda yang tergabung dalam Purna Paskibraka Indonesia Kabupaten Klaten tidak akan mudah dimasuki ideologi yang mengancam NKRI seperti ideologi komunis, ISIS dan Gafatar. Mereka menyatakan bahwa Pancasila sebagai ideologi bangsa adalah suatu hal yang tidak bisa ditawar dan tidak bisa diganggu gugat. Kedua, mereka menolak ideologi yang bertentangan dengan Pancasila, seperti komunisme dan terorisme. Bagi mereka, Pancasila merupakan pedoman dalam hidup berbangsa dan bernegara.

\section{Sikap Terhadap Simbol-Simbol Negara}

Para anggota Purna Paskibraka Indonesia Kabupaten Klaten mampu memperlakukan bendera, lambang negara, dan lagu kebangsaan dengan baik. Sikap ini ditunjukkan dengan menjadi petugas pada upacara bendera di sekolah masing-masing. Sekolah di Kabupaten Klaten kini mewajibkan upacara bendera setiap hari Senin dan setiap tanggal 17 setiap bulannya. Paparan di atas dapat dilihat bahwa para anggota Purna Paskibraka Indonesia Kabupaten Klaten memiliki pemahaman yang baik tentang lambang negara beserta aturan penggunaannya. Pemahaman yang sudah dipahami oleh Para anggota Purna Paskibraka Indonesia Kabupaten Klaten dan dengan diadakannya upacara bendera secara rutin, maka dapat mendukung ketahanan wilayah di Kabupaten Klaten.

\section{Kebanggaan Terhadap Jatidiri Bangsa Indonesia}

Pengaruh terhadap aspek politik terlihat pada kepedulian terhadap kondisi bangsa dan kondisi daerah setempat. Sebagai contoh pada waktu Pilkada atau Pemilihan Kepala Daerah. Pada waktu Pilkada serentak 9 Desember 2015, Purna Paskibraka Indonesia Kabupaten Klaten memberikan himbauan kepada para anggotanya lewat pesan berantai di social media yang berisi ajakan untuk menyalurkan hak pilihnya dan memilih pemimpin yang baik. Bukan berarti memihak pada salah satu calon tertentu, himbauan ini lebih pada gerakan moral agar para pemuda yang tergabung dalam Purna Paskibraka Indonesia Kabupaten Klaten ikut berpartisipasi dalam kegiatan politik. Dengan ini Purna Paskibraka Indonesia Kabupaten Klaten menunjukkan bahwa mereka memiliki kepedulian terhadap kondisi bangsa, memiliki kepedulian terhadap daerahnya, tidak acuh atas peristiwa aktual yang sedang terjadi. Pendidikan politik ini penting sebagai sarana mendidik para pemuda agar tidak apatis terhadap kondisi bangsa dan kondisi daerahnya. Hal ini menunjukkan bahwa Purna Paskibraka Indonesia Kabupaten Klaten memiliki pengaruh terhadap ketahanan wilayah Kabupaten Klaten, khsusunya dalam bidang politik.

Pada aspek ekonomi, Purna Paskibraka Indonesia Kabupaten Klaten kurang menunjukkan partisipasinya. Meskipun dalam nomenklatur kepengurusan terdapat bidang Bina Usaha dan Koperasi, Purna Paskibraka Indonesia Kabupaten Klaten belum mampu memberdayakan bidang tersebut. Hal ini disebabkan karena sebagian besar anggota Purna Paskibraka Indonesia Kabupaten Klaten masih berstatus pelajar. Kesadaran mereka terhadap aspek ekonomi masyarakat masih kurang. 
Irwan, Muhamad Supraja, Ahmad Zubaidi -- Dinamika Aktualisasi Diri Pemuda Rantau Dan Implikasinya Terhadap Ketahanan Pribadi (Studi Pada Mahasiswa Rantau Asal Sumatra Barat Di Asrama Putri Bundo Kanduang Daerah Istimewa Yogyakarta)

Purwanegara (2006) mengatakan bahwa aspek sosial budaya merupakan aspek yang tidak kalah pentingnya dalam upaya perwujudan ketahanan nasional Indonesia. Pada aspek sosial budaya, pengaruh Purna Paskibraka Indonesia Kabupaten Klaten terhadap ketahanan wilayah Kabupaten Klaten terlihat pada dua hal. Pertama, pada setiap anggota Purna Paskibraka Indonesia Kabupaten Klaten terdapat jiwa kebersamaan yang tinggi (korsa). Dari jiwa kebersamaan yang tinggi ini dapat mengasah nilai yang terkandung dalam sila ke 5 Pancasila yaitu keadilan sosial bagi seluruh rakyat Indonesia. Jiwa korsa yang dimiliki oleh para anggota Purna Paskibraka Indonesia Kabupaten Klaten diwujudkan dengan mengadakan kegiatankegiatan yang bersentuhan langsung ke masyarakat. Mereka membuat program dan kegiatan yang bersifat sosial-interaksional, sehingga dari kegiatan yang dilaksanakan ini mampu menciptakan kohesivitas sosial antara masyarakat dengan Purna Paskibraka Indonesia Kabupaten Klaten. Kedua, ditunjukkan dengan kebanggaan akan budaya asli bangsa Indonesia dan budaya daerahnya masing-masing. Selain itu, secara kelembagaan Purna Paskibraka Indonesia Kabupaten Klaten juga mengadakan kegiatan bersama dengan Adwindo Klaten (Asosiasi Duta Wisata Kabupaten Klaten). Kegiatannya berbentuk City Tour. Kegiatan City Tour ini adalah kegiatan berkeliling tempat-tempat wisata bersejarah di Klaten. Pada saat singgah di obyek wisata, duta wisata dari Adwindo memberikan penjelasan kepada anggota Purna Paskibraka Indonesia Kabupaten Klaten tentang sejarah dan makna obyek wisata tersebut sehingga para anggota Purna Paskibraka Indonesia Kabupaten Klaten mendapatkan pengetahuan tentang sejarah sekaligus budaya dari obyek wisata tersebut, dengan memiliki pengetahuan tentang sejarah dan budaya daerah setempat akan memberikan pengaruh terhadap ketahanan wilayah Kabupaten Klaten khususnya dalam aspek sosial budaya.

\section{Semangat Rela Berkorban Untuk Bangsa dan Negara}

Pada aspek pertahanan dan keamanan, pengaruh Purna Paskibraka Indonesia Kabupaten Klaten terhadap ketahanan wilayah Kabupaten Klaten terlihat pada semangat rela berkorban untuk bangsa dan negara. Darmono (2010: 2) mengatakan bahwa dinamika situasi global pascaperang dingin ternyata telah menimbulkan persepsi ancaman yang semula lebih berorientasi kepada ancaman militer menjadi ancaman multidimensi yang mencakup aspek politik, ekonomi, dan sosial budaya yang kemudian mendorong terjadinya revolusi paradigma sektor keamanan. Perubahan paradigma ini juga telah mengubah lingkup pengelolaan Kamnas yang semula lebih berorientasi kepada negara (state centered security) menjadi berorientasi kepada masyarakat (people centered security). Konsep keamanan komprehensif tersebut mempromosikan apa yang dinamakan human security untuk menggantikan kerangka pemikiran yang berorientasi pada statecentrism, yang sama sekali meninggalkan ruang lingkup pengertian keamanan untuk merefleksikan ketidakamanan yang biasa dihadapi oleh manusia baik individual, kelompok, atau masyarakat yang bersifat kronis dan kompleks dalam kaitannya dengan kondisi kehidupan sehari-hari (Muladi, 2007).

Semangat rela berkorban untuk bangsa dan negara yang ditunjukkan Para anggota Purna Paskibraka Indonesia Kabupaten Klaten diwujudkan dengan tiga hal, yaitu (1) 
Ikut aktif dalam kegiatan Purna Paskibraka Indonesia Kabupaten dan aktif membina Paskibraka di sekolah masing-masing di tengah kesibukan sebagai pelajar. Di tengah kesibukan para anggota Purna Paskibraka Indonesia Kabupaten Klaten sebagai pelajar, mereka masih meluangkan waktunya untuk aktif berkegiatan di Purna Paskibraka Indonesia dan aktif membina Paskibraka di sekolahnya masing-masing. Hal ini merupakan perwujudan nyata dari semangat rela berkorban untuk bangsa dan negara. (2) Para anggota Purna Paskibraka Indonesia Kabupaten Klaten menyadari bahwa sebagai generasi penerus bangsa memiliki tanggung jawab yang besar untuk membangun bangsa ini. Hal ini diwujudkan dengan patuh terhadap hak dan kewajibannya sebagai warga negara. Berbekal kedisiplinan yang telah ditanamkan, patuh terhadap hak dan kewajiban sebagai warga negara merupakan perwujudan dari semangat rela berkorban untuk bangsa dan negara. Yang ketiga, mereka memiliki impian dan gagasan untuk masa depan Indonesia yang lebih baik. Sikap rela berkorban tersebut menunjukkan bahwa pemahaman, kesadaran, dan komitmen terhadap bela negara memiliki pengaruh terhadap ketahanan wilayah khususnya pada aspek pertahanan dan keamanan.

\section{SIMPULAN}

Berdasar penjelasan di atas dapat ditarik simpulan sebagai berikut.

Pertama, Purna Paskibraka Indonesia Kabupaten Klaten telah melakukan partisipasi dalam kegiatan bela negara di Kabupaten Klaten melalui berbagai kegiatan, yaitu rangkaian kegiatan upacara bendera 17 Agustus, kegiatan yang bersifat interaksi sosial, kompetisi antar Paskibra, dan kegiatan bersifat aksi. Partisipasi tersebut menghasilkan tiga hal yang terkait dengan bela negara yakni pemahaman terhadap bela negara, kesadaran terhadap bela negara, dan komitmen terhadap bela negara. Partisipasi yang dilakukan oleh Purna Paskibraka Indonesia Kabupaten Klaten menunjukkan bahwa ada keterlibatan mental dan emosional dalam melakukan bela negara. Para anggota Purna Paskibraka Indonesia Kabupaten Klaten menunjukkan rasa memiliki yang tinggi terhadap bangsa dan negara Indonesia, memiliki kebanggaan terhadap jatidiri sebagai bangsa Indonesia, dan memiliki cita-cita untuk membangun bangsa Indonesia agar menjadi bangsa yang besar.

Kedua, pemahaman, kesadaran, dan komitmen yang tertanam di dalam diri para pemuda yang tergabung di dalam Purna Paskibraka Indonesia Kabupaten Klaten memiliki pengaruh terhadap terhadap ketahanan wilayah. Pengaruh secara langsung terlihat pada aspek pancagatra. Pengaruh terhadap pancagatra terdapat pada aspek ideologi, aspek politik, aspek sosial budaya, dan aspek pertahanan keamanan. Satu aspek lainnya yaitu aspek ekonomi tidak memiliki pengaruh karena Purna Paskibraka Indonesia Kabupaten Klaten belum memiliki pemahaman terhadap kegiatan-kegiatan pemberdayaan ekonomi masyarakat sehingga tidak melaksanakan kegiatan yang terkait dengan aspek ekonomi.

Ketiga, organisasi Purna Paskibraka Indonesia Kabupaten Klaten mampu membangun sistem ketahanan wilayah di Kabupaten Klaten dengan cara melakukan sinergi dengan instansi terkait seperti Komando Distrik Militer dan Dinas Pariwisata, Kebudayaan, Pemuda dan Olahraga. Sinergi lintas instansi dan organisasi ini mampu mewujudkan Kabupaten Klaten sebagai wilayah yang aman dan tangguh dari sisi 
Irwan, Muhamad Supraja, Ahmad Zubaidi -- Dinamika Aktualisasi Diri Pemuda Rantau Dan Implikasinya Terhadap Ketahanan Pribadi (Studi Pada Mahasiswa Rantau Asal Sumatra Barat Di Asrama Putri Bundo Kanduang Daerah Istimewa Yogyakarta)

ideologi, politik, ekonomi, sosial budaya, dan pertahanan keamanan.

\section{DAFTAR PUSTAKA}

Abdullah, I., 2006., Konstruksi dan Reproduksi Kebudayaan., Yogyakarta: Pustaka Pelajar.

Badan Pusat Statistik Kabupaten Klaten, 2014., Indikator Kesejahteraan Rakyat Kabupaten Klaten 2014, (Internet) https:// klatenkab.bps.go.id/ (Diakses Tanggal 15 Mei 2016).

Darmono, B., 2010., “Konsep dan Sistem Keamanan Nasional Indonesia", Jurnal Ketahanan Nasional, No. XV (1), April 2010, hal. 1-41, ISSN. 0853-9340.

Kodiran, 2006., "Perubahan Sosial dan Ideologi: Sebuah Telaah Perspektif Perubahan Sosial dan Ideologi Nasional", Jurnal Ketahanan Nasional, No. XI (2), Agustus 2006, hal. 69-74, ISSN. 08539340.

Muladi., 2007., "Konsep "Comprehensive Security" dan Ketahanan Nasional", Jurnal Ketahanan Nasional, No. XII (3), Desember 2007, hal. 1-10, ISSN. 0853-9340.

Pemerintah Kabupaten Klaten, 2016., Website Pemkab Klaten, (Internet), http:// klatenkab.go.id/, (Diakses Tanggal 15 Mei 2016).
Purwanegara, Dani, 2006., "Pembinaan Stabilitas Nasional Dinamis dan Manajemen Perubahan", Jurnal Ketahanan Nasional, No. XI (2), Agustus 2006, hal. 19-50, ISSN. 0853-9340.

Setiawan, M Budi., 2009., Mozaik Gerakan Pemuda Kontemporer., Jakarta: Kementrian Negara Pemuda dan Olahraga RI Deputi Bidang Pengembangan Kepemimpinan Pemuda.

Siswanto, Edy Permana Wahyu., 2013, "Partisipasi Masyarakat Terhadap Bela Negara Dalam Rangka Ketahanan Wilayah (Studi Kasus di Kelurahan Pasir Gunung Selatan Depok-Jawa Barat)", Tesis, Yogyakarta: Program Pascasarjana Universitas Gadjah Mada.

Soekidjan, S., 2009., Komitmen Organisasi Apakah Sudah Dalam Diri Anda? Jakarta: Rineka Cipta.

Strauss, A dan Corbin, J., 2003, DasarDasar Penelitian Kualitatif: Tatalangkah dan Teknik-Teknik Teoritisasi Data., Yogyakarta: Pustaka Pelajar.

Sudaryono., 2012., Dasar-Dasar Evaluasi Pembelajaran., Yogyakarta: Graha Ilmu.

Sudijono, A., 1999., Pengantar Statistik Pendidikan., Jakarta: Raja Grafindo 